\title{
Commercialization of Indian Nationalism: Current Status and Associated Risks
}

\author{
Alok Balhwan \\ Department of Public Administration, IGNOU, Delhi
}

\begin{abstract}
India is a nation in making. She has a history of being a victim of colonialism. Thus her citizens are very emotional towards anything related to nationalism. These emotions are manipulated by political parties, media houses, entertainment industry and business firms. When a nation's patriotic feelings are evoked for commercial gains, it is called Commercialization of Nationalism. In this paper, efforts have been put to search and identify various such current instances from all walks of life. Then the phenomenon has been analyzed in detail and contradictions have been brought to light. This commercialization process has its dangers for the society which are also discussed. This paper concludes by saying that nationalism should not be commercialized and there should be a healthy competition among the business firms so that the consumer is free to make an informed rational decision.
\end{abstract}

Keywords: Nationalism; Commercialization; business firms; media

\section{Introduction}

Nationalism is a global concept and nationalists are influenced by a wide range of models. Nationalism has spread along the lines of direction which have to be understood more in terms of degrees of success. Asian nationalism beyond Japan modeled itself on Japanese nationalism; African nationalism after 1947 in part was modeled on Indian success. [11] The concept of nationalism in India is not a new concept. It is something Mahatma Gandhi used very effectively to rally people against British colonial rule, appealing to people to boycott foreign goodsincluding lighting bonfires of them. It became the key rallying call for the Civil Disobedience movement Gandhi launched; in part, it was also a campaign for Indian handlooms. [4] India is a state-nation and is a nation in making. She has a history of being a colony. Thus citizens are very emotional towards everything related to nationalism. These emotions are manipulated by political parties, media, entertainment industry and business firms. Literally speaking, commercialization is the process of managing or running something principally for financial gain. Commercialization can be analyzed from various perspectives but if we see from socio-cultural perspective then it can be studied as the interplay of business firms with local festivals, customs, religions, languages, geographical diversities and lastly patriotic national feelings. This paper will touch upon all aspects but will discuss commercialization of nationalism specifically and that too in the light of current events.

\section{Background}

Commercialization of nationalism is a conscious effort to manipulate the patriotic feeling of people in general for materialistic gain. This phenomenon is neither new nor unique to India.

If we go a little back in Chinese history then we will find that in the 1930s, Shanghai's image (much like its image today) was that of a large cosmopolitan city, advertising products from around the world. It was soon countered by campaigns to promote the consumption of Chinese- manufactured goods. This campaign was particularly against the use of Japanese products because of its strained relations due to the Japanese war of aggression (1937-45). Not only did it encourage Chinese nationalism, but it also went a long way in promoting China as a modern nation that did not have to rely on foreign products. [8]

Foreign companies had to worry about political risk in China, with demonstrations outside American fast-food restaurants and mobs burning Japanese cars. [5]

Generally speaking, history tells us that the State or influential oligarchs have sought to push the message of "Nation First" onto the population from time to time. [8]

In India, there is a famous slogan by an Indian nationalist party, which used to say in the 1990s, "We want computer chips, not potato chips."[3]

\section{Aspects of Commercialization}

World over businesses have devised ways to earn profit through establishment of a 'relationship' with socio-cultural aspects of citizens like local festivals, customs, social institutions, religions, languages, geographical diversities. This argument is corroborated by the following examples.

The World Gold Council decided to put a lot of money into marketing festivals such as Akshaya Trithya so that people do more and more shopping. Both Indian and foreign companies have been promoting Valentine's Day, and it has been quite successful with young, urban couples. [3]

Recently, P C Jeweller has launched a TV commercial which showcases the love and bond between the couple, which is enhanced with the jewellery gifts exchanged between them. [12]

A dash of cow urine in a handful of Patanjali products, including soap and floor cleaner, burnishes its Hindu credentials. [6]

\section{Volume 6 Issue 10, October 2017}




\section{International Journal of Science and Research (IJSR) \\ ISSN (Online): 2319-7064}

Index Copernicus Value (2015): 78.96 | Impact Factor (2015): 6.391

Micromax's recent Angrezipanti advertisement features TV funny man Kapil Sharma in which emotional attachment with language is evoked to sell its products. [1]

\section{Current Instances of this Phenomenon}

Business firms seek to exploit contemporary or historic political situations for commercial gain. Globally, as "Trumpian" nationalism was surging in the United States before the presidential election in 2016, the beer brand Budweiser decided to rebrand itself as "America", in the months leading up to the election. [8]

Here in India, the Indian Army's cross-border surgical strikes on 29 September, 2016 to neutralize launch pads for terrorists located in Pakistan-occupied Kashmir has become a watershed moment and a surge of nationalistic fervour seems to be sweeping the country. [4] Here are a few of such instances:

Cinema Owners and Exhibitors Association (COEA) declared that they would not be screening films featuring Pakistani artistes, including actors and music directors. Earlier, the Indian Motion Picture Producers' Association, another film industry lobby group, imposed a similar ban. It's nothing but the business of nationalism. [4]

A boycott of Chinese firecrackers inspired mostly by word of mouth is gaining momentum ahead of Diwali-the festival of lights. [4]

A number of companies such as Bajaj and Pepperfry sought to celebrate Indian "victory"' by portraying the armed forces in their advertisements. [8]

Bajaj Auto, which recently rolled out the second leg of its campaign for $\mathrm{V}$, the motorcycle that is made from the metal body of the warship INS Vikrant used in the 1971 India-Pakistan war. [10]

Online furniture marketplace, Pepperfry, has also been running a festive Diwali campaign, Iss Diwali Kuch Badal Ke Dekhiye with one of the ad-spots showing how a junior officer gets a wooden cupboard as a Diwali gift. [10]

Delhi-based fast food outlet Burger Singh announced a 20\% discount on its items to mark the surgical strikes. [10]

Online mobile recharge platform MobiKwik offered 20\% cashback with a special code "ISTSTRIKE". [10]

Online shopping platforms use ' 1947 ' as discount coupon on the occasion of $15^{\text {th }}$ Aug and $26^{\text {th }}$ January.

Patanjali's has recently launched an advt. campaign "together we can turn the SWADESHI dream of Mahatma Gandhi, Bhagat Singh and Ram Prasad Bismil into a reality". [1]

Aamir Khan-Snapdeal episode in which Aamir's views on nationalism had a reactionary effect on Snapdeal which had big financial ramifications. [1]
Other related media advertisements which evoke patriotic feelings include NDTV India's 'zubaan pe sach dil me India'; TATA Salt's 'desh ka namak'; Kajaria's 'desh ki mitti se bni tiles'; MDH Masala's 'yahi to hai asli India...the real taste of India'; Sahara Group's 'Bharat hai hamara, hum hai Sahara'.

Several TV channels are named after India e.g. India TV, India News, News World India, NDTV India etc. One news channel is named even 'Republic'.

In India, Cricket is often termed as national hobby, so in that sense birth of IPL can be termed as commercialization of nationalism.

The portrayal of nationalism in the recently released film The Ghazi Attack through national anthem did nothing to advance the story, but only served as a means to capitalize on the nationalist sentiments running high in the country. [8] The above mentioned list of examples is not exhaustive and many more instances can be easily searched.

\section{Analysis of the phenomenon}

Foreign business firms are striving to compete with 'nationalism' of domestic firms in their own way. To compete with the local (U.S) beer brand Budweiser, a Belgian beer, Anheuser-Busch InBev, rebranded itself as "America". While the campaign was largely unsuccessful commercially, it certainly highlights the emotions advertising taps into, and the impact it seeks to have. [8]

Likewise, Lufthansa's current ad campaign in India features the line "More Indian than you think." Even phones from Chinese electronics major Xiaomi arrive with big "Made in India" stickers across the front of the box. [5]

Sri Sri Ravi Shankar and Gurmeet Ram Rahim have already entered the business to compete with Baba Ramdev. Others will follow. It does not take a marketing guru to figure out how easily followers can be turned into shoppers. [6]

Experts say sensitive issues such as national security must be handled with care, with attempts by some brands to leverage the buzz around surgical strikes failing miserably and attracting criticism e.g. Burger Singh and MobiKwik had to withdraw the offer after scathing attacks on social media. [10]

According to Jitender Dabas, chief strategy officer, McCann Worldgroup India, Being contextual and being opportunistic aren't too distant from each other if not calibrated properly, especially when it is about taking a slightly exalted position by choosing a subject like patriotism. The brand's stature and past association on similar issues always plays an important role. Thus 'Hero' has got benefit. [10]

Uday Mohan, managing partner, north and east India, Havas Media, thinks that when it comes to sensitive issues, right creative execution is crucial. There should be no sensationalism of the issue and there has to be a creative 


\section{International Journal of Science and Research (IJSR) \\ ISSN (Online): 2319-7064}

Index Copernicus Value (2015): 78.96 | Impact Factor (2015): 6.391

synergy between the brand message and the communication. [10]

Saurabh Uboweja, chief executive and chief brand strategist, Brands of Desire, believes brands have a Herculean task in trying to leverage topical sensitive subjects. If done wrong, brands can come across as opportunist. [10]

According to him, not everyone takes to such campaigns positively unless the brand proposition being communicated or the communication itself is authentic, has a deeper purpose and is believable or relatable. Like in the Bajaj V campaign, they have developed a complete brand identity around INS Vikrant, taking a long-term view on patriotism. It's a choice the brands have made between short-term brand recall and long-term equity creation. [10]

The business of nationalism clearly has a case. But it is also apparent just this appeal alone won't make business sustainable - it can neither be a necessary nor a sufficient condition. It can trigger a surge in sales but eventually it will pass and the consumer's rational instincts will take over. And an Indian consumer is inevitably driven by the valuefor-money principle and, of late, also increasingly drawn to quality products. [4]

\subsection{Contradictions}

A few random instances highlighting the contradictions are being discussed here:

Baba Ramdev has taken full commercial advantage by evoking patriotism, though he himself is the most regressive shade of social conservatism. Indian lawmakers have accused him of selling medicines that claim to encourage the birth of male children. He advertises "cures" for homosexuality in his ashram and has a running feud with Bollywood's actresses, whom he has condemned as "characterless." He fought against the decriminalization of homosexuality all the way to India's Supreme Court. [5]

Swadeshi Jagran Manch, the economic wing of the family of organizations that includes Modi's ruling Bharatiya Janata Party, has seized on the idea of a boycott of Chinese imports, which totaled $\$ 62$ billion in year 2015. This view contradicts the stated policies of the Modi government. [5]

Patanjali is not facing any backlash from Indian consumers or government for promoting nationalism in an era when the Indian Prime Minister is attempting to attract foreign investments and companies for the Make in India campaign. [2]

When Supreme Court made it compulsory for cinema theatres to play the national anthem with the image of the national flag prior to screening films, it specifically ordered ban on commercial exploitation of the national anthem. This means no tele-serial, advertisement or theme songs for any event could use the anthem partly, as had been the popular practice. [13]

Indian Cricket team, a symbol of our nationalism, is also the brand ambassador of Chinese products. Oppo has bagged the rights to Indian national cricket; Vivo has won the IPL sponsor tag. BBK Electronics, which overthrew Apple in China, owns both these smart phone companies. [9]

\subsection{Associated Risks}

Risks associated with the phenomenon of commercialization of nationalism are being discussed by quoting specific factual instances:

When taken to task for its advertisements, Patanjali's Balakrishna, has said that they are not part of ASCI (Advertising Standards Council of India) and so don't fall under its purview. [1] Such situation is dangerous because it destroys the reputation of institutions like ASCI and also sets a wrong precedent.

According to Santosh Desai, MD and CEO, Future Brands, one may see nationalism seep into tonality but a lot of what brands do is posturing: both on the liberal and the nationalistic side. However this world simply has far less of a license to go all out. There's no way a $P \& G$ or a Unilever can get away with what Trump can get away with. [1]

With reference to Aamir-Snapdeal incident, a stray comment from an endorser can quickly become a lightning rod for the brand and it's messaging to be subsumed by a vigorous, angry Indian nationalism. [1]

The call for trade embargo on China has been justified to teach her a lesson for its unconditional support to India's socalled nemesis in the region - Pakistan.

Far from actually supporting the armed forces, nationalist marketing campaigns seek to integrate a diverse population under a singular identity for the purpose of making their products relatable to everyone.

However, the world order is moving towards increasing isolationism, despite globalisation having connected nationstates and their populations in irreversible ways. Protecting economic and political interests for all states, regardless of what populist rhetoric may loudly proclaim, requires consistent engagement with the rest of the world. As the world faces ever-evolving challenges from traditional security threats such as terrorism, and non-traditional security threats like climate change, it has become imperative for nations to come together to ensure global peace and stability. And hence, it is important to challenge the growing trend of hyper-nationalism. [8]

Hypernationalism essentially undermines the importance of a globalised, collaborative world order. Political leaders fuel this emotion by blaming the social problems such as unemployment, terrorism, and fast-changing social demographics on an increasingly interconnected world. Marine Le Pen of France, Greet Wilders of the Netherlands, Donald Trump of the United States and even Indian Prime Minister Narendra Modi have appealed to their citizens' sense of patriotism to undermine regional and global engagement. With the commercialization of nationalism, states and oligarchs use print, social media and cinema as means to integrate their target populations and further this

\section{Volume 6 Issue 10, October 2017 www.ijsr.net}




\section{International Journal of Science and Research (IJSR) \\ ISSN (Online): 2319-7064 \\ Index Copernicus Value (2015): 78.96 | Impact Factor (2015): 6.391}

hyper-nationalist agenda. And therefore, while individual instances of commercialization of nationalism may seem harmless, in the long run, the trend may have serious implications on the States' foreign policies, and ultimately, the liberal world order. [8]

\section{Conclusion}

Business firms should conduct their activities purely as per the principles of economics. The consumer should be correctly informed about the product and its specifications/quality etc so that an informed decision can be made by the consumer. Consumer should not be misled by evoking nationalist feelings. If all firms use nationalism then it will confuse the consumer and if only a few firms use it then it will not be 'level playing field' for the other firms. Also, when a business firm intends to tap into nationalist emotions, it indirectly tries to paint its competitors as antinational which is very unethical. It has also been observed that sometimes national symbols are used in a way that is derogatory. In conclusion, it is pertinent to say that nationalism should not be commercialized and there should be a healthy competition among the business firms so that the consumer is free to make an informed rational decision.

\section{Acknowledgement}

The author is thankful to his son, Aman Balhwan, for constant cooperation.

\section{References}

[1] Balakrishnan, R. (2016, Aug 10). Reclaiming Bharat: Can ads \& brands become nationalistic without jingoism. ET Bureau. Retrieved from https://economictimes.indiatimes.com

[2] Kashyap, K. (2016, Oct 24). Nationalist Startup Patanjali Ayurved Leads Natural, Organic Trend As Indian Consumers Need Shift. Forbes. Retrieved from https://www.forbes.com

[3] Cayla, J. (2009, May 22). How do foreign companies market to India. Yale Insights. Retrieved from http://insights.som.yale.edu

[4] Padmanabhan, A. (2016, Oct 17).The business of nationalism. Live Mint. Retrieved from http://www.livemint.com

[5] Sharma, M. (2016, Oct 12). India's open for business, assuming you're Indian. Live Mint. Retrieved from http://www.livemint.com

[6] India's Patanjali takes on Western consumer-goods firms (2017, Apr 29). The Economist. Retrieved from https://www.economist.com

[7] Cook, I. (2017, July 24). Patanjali takes a very nationalist view of its business. BT Online. Retrieved from http://www.businesstoday.in

[8] Kulkarni, T.B. (2017, Apr 14). The Commercialisation of Nationalism. Huffpost. Retrieved from http://www.huffingtonpost.in

[9] Abraham, D. (2017, July 5).Vivo, Oppo, IPL, and the Chinese invasion of cricket. The Hindu Read. Retrieved from http://www.thehindu.com
[10] Tewari, S. (2016, Oct. 21) Surgical strikes: Are brands cashing in on nationalism in ad campaigns. Live Mint. Retrieved from http://www.livemint.com

[11] Breuilly, J. (2013, Jun 03). A history of nationalism. OUPblog. Retrieved from https://blog.oup.com/2013/06/oxford-handbook-historynationalism/

[12]PC Jeweller Releases TVC With Brand Ambassadors Akshay Kumar And Twinkle Khanna(2017,Oct 16). EXCHANGE4MEDIA NEWS SERVICE. Retrieved from http://www.exchange4media.com

[13] Mahapatra, D. (2016, Dec 01). Play nat'l anthem in cinema halls, audience must rise: SC. The Times Group. Retrieved from http://epaperbeta.timesofindia.com

Volume 6 Issue 10, October 2017

www.ijsr.net 